\title{
177. 3チャン祙レーザープリソターの使用経験
}

Experience of 3channel laser printer

$$
\begin{aligned}
& \text { 金沢大学医学部附属病院放射線部 } \\
& \text { O河 原 和 博 }
\end{aligned}
$$

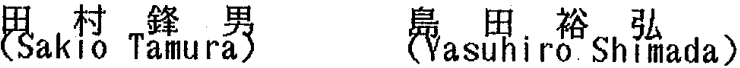

（目的） 平成 2 年 3 月よりコダック社レーザープリンター（KEL P ）にマルチモダリティシステ ム（KE I M）を接続して C T 3台のイメージを出力させることになった。このシステムの同時 入力による荤れやディスク容量の適否を使用上検討した。

（方法） 同時入力数の違いによる最短入力時間、標準的入力時間、1 日の処理枚数と時間帯による 処理枚数を計測した。

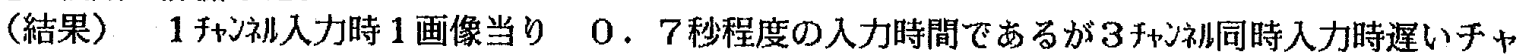
ンネルでは 2 秒程度となるが、実際の入力時には同時入力となることは、ほとんどなかった。また杊

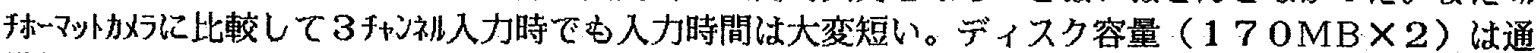
常使用状態では余裕があり、KE L Pのトラブル時にも十分と考えられる。

[設置装置]Lーサ”-プ似 Kodak Ektascan Laser Printer (KELP)

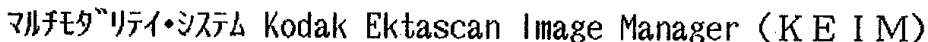

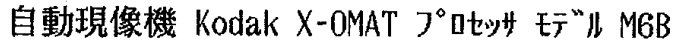

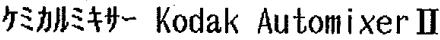

[人力装置] GE C T 9800 Hilight

X線CT装置 YMS C T 9000

GE C T 8800

各C T別データ量

マは川ッ久画像容量 画像容量(MB)

装置名 (縦X横) /画像(MB) /FILM(12丁P)

CT9800 $556 \times 578 \quad 0.322 \quad 3.864$

CT9000 $340 \times 415 \quad 0.142 \quad 1.704$

CT8800 $340 \times 415 \quad 0.142 \quad 1.704$

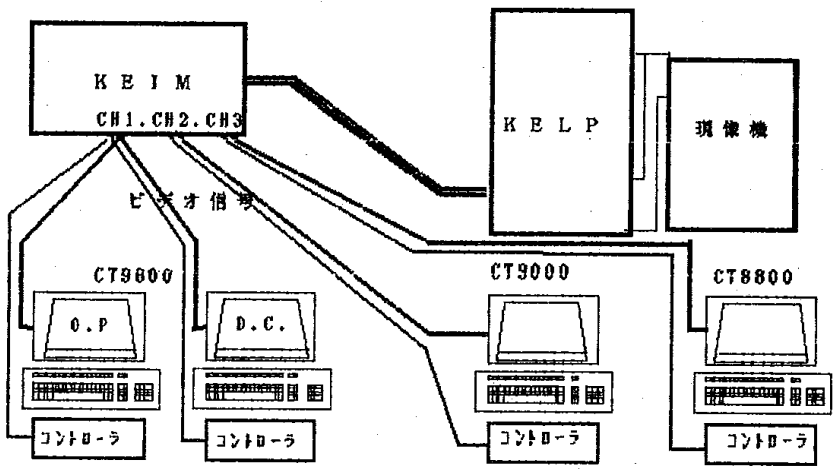

C T 9800 だけでのKE I M登録可能数=(170MB×2)/3.864=88枚 平均灼イズ $((3.864+1.704+1.704) / 3)=(170 \mathrm{MB} \times 2) / 2.424=140$ 枚 最短入力時間 ( $\mathrm{sec}$ /画像)

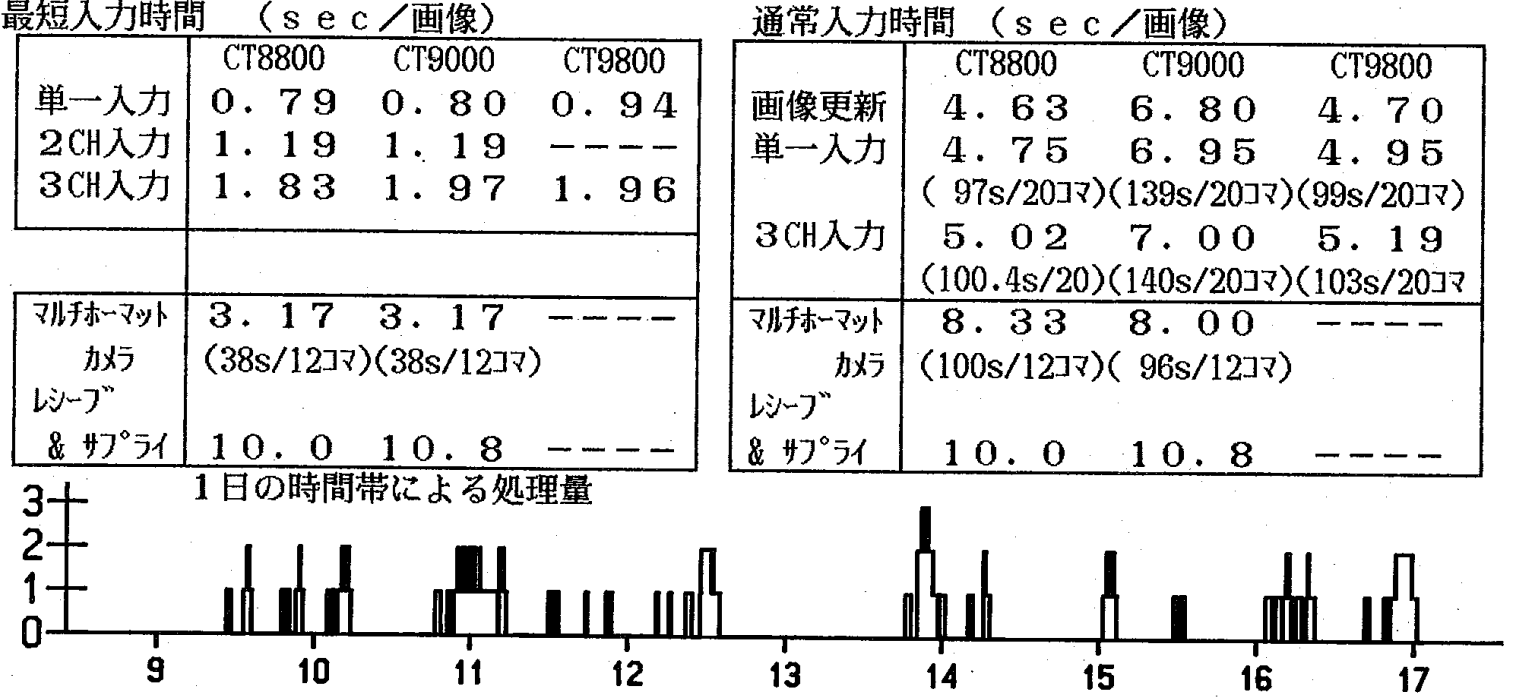

